\title{
Hematopoietic Stem Cell Research
}

National Cancer Institute

\section{Source}

National Cancer Institute. Hematopoietic Stem Cell Research. NCI Thesaurus. Code C16201.

General research on hematopoietic stem cells and research on their use in medicine. 